\title{
Successful Leadership in Rural Schools: Cultivating Collaboration
}

\author{
Jane P. Preston
}

\author{
Kristopher E. R. Barnes \\ University of Prince Edward Island
}

This article is a literature review of the professional competencies and personal qualities commonly associated with successful leadership in rural schools. Multiple definitions of the term rural are provided. A delimitation of this research is that findings reflect literature published from 2005-2015, positioning this document as a current analysis of rural leadership. A limitation of the article is that the research predominantly emanates from rural American, Canadian, and Australian settings, restricting a global application of results. The findings are represented via two overarching themes. Successful rural principals promote people-focused relationships with staff, students, parents, and community members. Second, rural principals have the opportunity to be agents of change through balancing local and district policies and through enacting instructional leadership. At the root, both of these themes reveal the importance of rich collaboration with members of the school community. This research is pertinent to researchers, government leaders, policymakers, school leaders, teachers, parents, and community members interested in understanding and responding to the demands of rural schools.

Keywords: successful rural principals; benefits of rural principalship; document analysis

Studies have documented that successful leadership is a catalyst for improved student achievement and wellbeing (e.g., Day et al., 2011; Dinham, 2008; Heck \& Halliger, 2011; Leithwood, Harris, \& Hopkins, 2008; Louis, Dretzke, \& Wahlstrom, 2010; Moffitt, 2007; Robinson, 2011; Sebastian \& Allensworth, 2012). However, when reviewing this extensive research, it is obvious that a limited number of these studies focus on how school leaders successfully meet student needs in unique geographical contexts - namely, in rural schools.

This attention to rural is significant for a number of reasons. First, school leadership is informed by the particulars of the school community and its geographical setting; yet, literature about successful school leadership is often unrelated to situational realities and geography (Clark \& Stevens, 2009; Starr \& White, 2008). Otherwise said, although the context of rural school leadership demands differentiated attention, there is paucity of research on this specialized focus. Another reason why attention to rural leadership is important is that, across the globe, rural students represent a large percentage of school enrollment numbers. For example, within the United States, about one-third of schools are located in rural communities, and about $24 \%$ of American student are identified as rural (National Center for Education Statistics, 2013). A third reason to focus on rural school leadership is because, worldwide, studies reveal a marked discrepancy between the educational outcomes of urban and rural students. Although not always the case (e.g., Jordan, Kostandini, \& Mykerezi, 2012), urban students tend to outperform rural students (Alberta Government, 2012; Canadian Council on Learning, 2006; Hnatkovska \& Lahiri, 2013; Lamb, Glover, \& Walstab, 2014; NSW Government, 2013; OECD, 2013; Panizzon, 2012). In further contemplating this point, one way to promote student achievement and wellbeing is, first, to recognize what successful rural principals do and then use that information to capitalize on those constructive leadership actions and behaviors. Under these premises, we write this literature review, which documents effective school leadership within rural communities. ${ }^{1}$ More specifically, we identify personal and professional skills, qualities, practices, and competencies of successful rural principals.

The results of this article are meant to serve researchers, policymakers, educators, and community members interested in recognizing the effective attributes of the rural principalship. In particular, it is hoped that the information herein will help to inform policymakers and leaders charged with establishing

\footnotetext{
${ }^{1}$ For a sister article outlining the challenges associated with the rural principalship, see Preston, Jakubiec, and Kooymans (2013).
} 
educational directives for rural schools. A review of this work may assist in applying a rural lens to rural school leadership (Wallace \& Boylan, 2007).

Donning this rural perspective requires a nuanced level of comprehension of the uniqueness of rural education at the macro level, in addition to recognition of the differences between rural and urban schools at a micro level (Clarke \& Stevens, 2009). As well, the information, herein, is intended for rural principals, themselves. Equipping rural principals with knowledge of the benefits associated within their rural geographical context may serve as an inspiration and/or a type of roadmap toward school improvement via effective leadership.

\section{Delimitations, Limitations, and Definitions}

Writing a literature review involves the identification, collection, analysis, synthesis, and evaluation of a plethora of literary sources targeting a specific topic (Machi \& McEvoy, 2012; Schwandt, 2007). To offer the most up-to-date information possible, during the literature exploration, we delimited our search to work published throughout the past decade (i.e., 2005-2015). With regard to limitations, although we attempted to access documents from across the world, due to confinements of our library databases and the overall accessibility of published work, the majority of retrievable literature reflected studies from the United States, Canada, and Australia. As well, most of the studies that did surface were small case studies involving two to 12 rural principals, thereby preventing the generalization of findings. Another limitation of this work pertains to a lack of a common definition of rural. For example, the Australian Bureau of Statistics (2011) defined an urban center as a "population cluster of 1,000 or more people" (para. 24). In the same country, the Australian Government (2013) defined rural and remote areas as any center with a population of less than 10,000. Similar to these descriptions, Statistics Canada, as articulated by Bollman and Alasia (2011), defined rural as any population in towns or municipalities outside the commuting zone of an urban center with a population of 10,000 or more. In the United Kingdom, Gov.UK (2015) reported rural to be settlements with less than 10,000 residents. The United States Census Bureau (2015) stated that rural includes populations existing outside urban clusters (of 2,500-50,000) or urbanized areas (of 50,000 or more). Although most of these citations recognizes rural as communities of less than
10,000 people, Statistics New Zealand (n.d.) and the United Nations (2013) indicated that there is no internationally recognized definition for rural.

In addition to the nonexistence of a common definition, during our review of the literature, numerous authors did not provide the rural definition used for their research. In dealing with this limitation, we automatically included literature that referred to communities with a population of 10,000 or less. If no quantifiable description of rural was provided, but the authors indicated their research was based on a rural context, we respected the authors' integrity and included the study in our findings.

\section{Research Design, Data Retrieval, and Analysis}

This article represents a literature review (or as we refer to as a document analysis) about the qualities, actions, and behaviors of successful rural principals. Bowen's (2009) described document analysis as the process of compiling and analyzing available published data on a particular topic, research question, or specific issue for the purpose of uncovering and/or understanding patterns and thematic consistencies. Glass (1976) noted document analysis as a synthesis of published work or an "analysis of analyses" (p. 3). Document analysis has been referred to as meta-synthesis (Boeije, 2008; Walsh \& Down, 2005), systematic review (Littell, Corcoran, \& Pillai, 2008), research synthesis (Cooper, Patall, \& Lindsay, 2009), and content analysis (Neuendorf, 2002, Prior, 2003). In considering these various perspectives, we define document analysis as a review of a topical body of published or publically accessible research, which is analyzed into major themes and sub-themes.

The first step of the research involved a literature search using the University of Prince Edward Island's (UPEI) (Canada) library database system. Through this system, we accessed books, chapters in books, textbooks, journal articles, dissertations, conference papers, newspapers, magazines, governmental policy documents, and other Internet accessible documents related to rural principalship. For these searches, we typed in keywords such as, "principal*", "educat*”, "admin*”, "school*”, "rural*”, "lead*”, "elementary", "high school," "success*," "effective*," "benefit*," "small," "administrator role," "administrator responsibility," "rural school*," and "rural-urban differences." We conducted searches using both solitary and amalgamated terms 
and, as mentioned above, only perused material within the past decade. To procure journal articles and other published research, we used the databases JSTOR, ERIC (EBSCOhost), PsycINFO, Google Scholar, Education Research Complete, and others. We examined resources by reading the title and abstract (where applicable), noting key words, and scanned at major and minor headings within the article. Then, if the document addressed our research purpose, we more fully browsed the content and printed it, if we found it pertinent to the research focus. This interrogation resulted in the collection of over 100 sources, although not all these sources were cited within the findings. With printed documents in hand, we read each source in detail underlining key passages and jotting paraphrased notes, findings, and/or phrases in the margins. The authors of this article met on a bi-weekly basis for about four months to discuss emergent overarching themes or patterns. We earmarked contradictions within the research and discussed the gaps in the research. Our analysis of documents and themes was a process similar to thematically analyzing or coding interview transcripts. As Patton (2015) explained, coding involves finding patterns, establishing categories from the patterns, and creating overarching themes based on the categories. During the last couple of face-to-face discussions, we made minor adjustments to themes and did a final search for any remaining articles potentially missed.

\section{Findings}

The findings represent about 40 research studies that addressed our purpose. Interestingly, other than a few of studies (e.g., Masumoto \& Brown-Welty, 2009; Renihan \& Noonan, 2012), no research that we found directly linked a successful rural principal to student achievement. Instead, most studies cited are qualitative in nature and depict successful leadership through data that represent personal experiences of principals and/or teacher and community member perceptions about successful school leaders. Two themes that emerged from the literature. First, successful rural principals promote people-centered leadership; second successful rural school leaders are change agents. Below, each of these themes is explicated through a number of sub-themes.

\section{People-Centered Leadership}

In reviewing the research, successful school rural leadership is founded on the healthy establishment and maintenance of relationships. More specifically, strong leadership is about nurturing interpersonal relationships with/among staff members, parents, students, and community stakeholders.

Collaboration among and with staff. Studies revealed that successful rural principals utilize a style of leadership reliant on teamwork. Such collaborative leadership improves the motivation, morale, and job performance of staff members (Lock, Budgen, \& Lunay, 2012; Renihan \& Noonan, 2012). Due to small staff numbers and rich social and professional networks, rural principals are in an ideal position to build trust among staff, promote collaboration among staff, and support student achievement goals (Chance \& Seguar, 2009; Irvine, Lupart, Loreman, \& McGhie-Richmond, 2010). For 12 teaching principals in rural Manitoba and Alberta (Canada), cooperative leadership was exemplified by a principal who asked a team of teachers to develop school goals and to perfect these goals at staff meetings and professional development sessions. Based on 10 rural principals in South Africa, Msila's (2012) found that principal success was supported by principals who shared leadership responsibilities with staff. In a survey distributed to 40 principals across North Carolina, Seipert and Baghurst (2014) found that rural principals utilized the expertise and experience of their staff to resolve school-related challenges. Bartling's (2013) doctoral work spotlighted four successful rural principals in Milwaukee (Wisconsin) and highlighted the effective rural principals acted in ways that endorsed "a power with rather than a power over" staff (p. iii). In two case studies, one located in the United States and the other in Cyprus, researchers found that successful rural school leadership was about encouraging teachers to collaborate and share pedagogical knowledge and experiences via peer-teacher observation and oral communication during staff meetings (Klar \& Brewer, 2014; Pashiardis, Savvides, Lytra, \& Angelidou, 2011). Additional studies relayed similar results - an effective rural principal promotes staff collaboration and capacitybuilding (Anderson et al., 2010; Ashton \& Duncan, 2012; Kawana, 2007; Tom, 2012; Wallin \& Newton, 2013). Such people-focused leadership not only generates self-pride and job satisfaction for teachers, 
but supports a teacher's personal wellbeing (Haar, 2007).

\section{Collaboration with individual staff members.} In addition to strong interpersonal relationships among and with staff members, a successful rural principal nurtures strong professional connections with individual staff members. In a study involving 21 American rural school principals, Barley and Beesley (2007) noted that it was common for rural principals to formally and informally meet with teachers to discuss specific students and student progress; teachers found such one-on-one meetings supportive. Similarly, Cortez-Jiminez' (2012) quantitative survey with 101 rural California principals found that $98 \%$ of principals found informal, impromptu meetings with teachers as being highly valuable for understanding staff professional development needs. Preston (2012) found that rural principals appeared to be more accessible, as compared to urban principals. A common component of these studies is that successful rural principals are available when teachers need them.

Collaboration with parents and students.

Largely because of the school's limited size, the school principal is in an ideal position to personally know every student and parent. This deep-rooted understanding of the academic and personal backgrounds of students assists in creating a learning environment that is responsive to the unique needs of students (Morrow, 2012; Renihan \& Noonan, 2012; Schuman, 2010). Newton and Wallin's (2013) Western Canadian study involving rural teacheradministrators found that not only did the dual role of teacher-leader support close relationship with students, it was a source of job satisfaction for principals. In a Cypriot case study involving five rural principals, principals created strong relationships with students by orally praising and publically rewarding students for their accomplishments (Pashiardis et al., 2011). As well, a number of studies showed that effective school rural leadership is about welcoming, listening, and responding to parental groups associated with school improvement efforts and advisory boards (Barley \& Beesley, 2007; Irvine et al., 2010).

Another aspect of a successful rural principal relates to fluid communication with parents (Latham, Smith, \& Wright, 2014). Barbour (2014) and Bartling's (2013) doctoral research, respectively involving three high schools principals in North Carolina and four female principals in Midwestern United States, documented that consistent communication with students, teachers, parents, and community members was a crucial component of successful school leadership. Such communication took a variety of forms, which included school newsletters, personal phone calls, and messages in church bulletins.

Collaboration and interaction with community stakeholders. Rural school leaders have a responsibility to nurture positive school-community relationships (Ashton \& Duncan, 2012). Jentz and Murphy (2005) indicated that successful rural principals build trusting relationship with community stakeholders. Principals foster strong relationships when they allow community members to use the school infrastructure. For example, Barley and Beesley (2007) described the vital role that the school and its principal played within one rural community by allowing access to the school building for weddings, craft shows, business meetings, and other social activities. The rural school also provided employment opportunities (e.g., bus drivers, cafeteria workers, teachers, teacher assistants, and administrative positions) for local community members and a space for community volunteerism (Barley \& Beesley, 2007). Individual interviews with 43 rural superintendents of school districts revealed these participants perceived effective principals to be leaders who valued close-knit relationships commonly epitomized between people living in rural communities (Cruzeiro \& Boone, 2009). Other studies highlighted a similar finding - the rural principal needs to value the concept of community (Budge, 2006; Harmon \& Schafft, 2009; Zacharakis, Devin, \& Miller, 2008).

Moreover, successful rural principals are often active citizens within the rural community, itself. That is, rural principals need to be seen as active community members, and often times, for these school leaders, "the boundary between the rural school and its community is blurry, at best" (Surface \& Theobald, 2015, p. 146). Morrow's (2012) research involving seven rural principals in British Columbia (Canada) showed that rural principals need to be both school leaders and active community citizens. Pashiardis et al. (2011) provided a specific example of how one rural principal was involved in the community. She regularly donated blood to the community health center and regularly attended local church services. Latham et al.'s (2014) mix-method research involving 63 rural principals participating in surveys and individual interviews emphasized the importance of the principal's role in community 
events and "how having an understanding of the dynamics of living in a rural community was both a positive and enabling attribute" of rural principals ( $p$. 7).

The close connection between a rural school and its community necessitates a kind of place leadership. Otherwise said, the notion of contextresponsive leadership is exemplified by principals who use their influence to promote a community-ascurriculum approach to education (Budge, 2006; Latham et al., 2014; Morrow, 2012). For example, in a case study involving four rural high schools in central Pennsylvania, principals strove to promote the social reproduction of the community by endorsing locally-determined curricula such as logging, carpentry and mechanics (shop), fish farming, and agriculture (Schuman, 2010). In order to successfully promote relevant, place-based programs, the rural principal needs to be geographically, culturally, and contextually literate about his/her community (Clarke \& Stevens, 2009; Lock et al., 2012). Also, with regard to place, a couple of studies highlighted that rural principals tend to enjoy a slower-paced lifestyle and a love for the physical landscape commonly associated with a rural school (Halsey \& Drummond, 2014; Lock et al., 2012). This land-based focus supports the leader's academic, personal, and local connections with the rural school and its students.

Collaboration through social capital. Social capital refers to informal and formal social bonds and network between people within personal and/or professional communities (Bourdieu, 1986; Coleman, 1988; Halpern, 2005; Putnam, 2000). Otherwise said, social capital is any type of personally or professional bond or network a person has with other people or organizations. Such interpersonal connections are exemplified through family networks, friendship ties, business associations, and links with influential people within organizations. Social capital is used, for example, when a group of connected people establish a goal and work toward achieving that aim. The effect of strong active stocks of social capital between and among the principal, parents, and community members is directly and indirectly reflected within a rural school environment in the form of community grants, volunteer support, sponsorship, awards, prizes, and various donations (Anderson \& White, 2011). Many studies relayed that successful rural principals use social capital to support school resources, community involvement in school, and student achievement (Agnitsch, Flora, \& Ryan, 2009; Klar \& Brewer, 2014; Lester, 2011;
Masumoto \& Brown-Welty, 2009). In other words, successful rural principals use the nascent and burgeoning stocks of social capital of the rural community to embellish the education and learning opportunities at the school.

\section{Principal as Change Agent}

A change agent is a person who, intentionally or unintentionally, supports and accelerates educational, social, cultural, and/or behavior change in an organization. A review of the literature highlights that rural principals are in an ideal position to lead change and to be an instructional leader.

Balance local and district needs. The ability to lead change is a feature of successful leadership in rural schools. However, Budge (2006) explained that, to be constructively influential, the principal needs to possess a thorough understanding of a community's value system, and the leader needs to be visible, accessible, and approachable to people within the school community. Pietsch and Williamson's (2009) study involving 21 interviews with new principals in remote areas of Australia showed that these individuals were confident that they could influence significant positive change, including the promotion of higher professional standards of teaching and improvements to student achievement. Additional studies spotlight that successful rural principal endorses the vision of the school, clearly articulates a plan in line with the vision, and, thereafter, stimulates change (Barbour, 2014; Bartling, 2014; Msila, 2012; Tom, 2012).

Particularly within a rural community, school decisions need to be informed by the specialized school community context, which is sometimes far removed from the school district's circumstances (Masumoto \& Brown-Welty, 2009). Moreover, rural principals are often called to endorse policy mandates predominantly designed for urban school settings (Morrow, 2012; Pietsch \& Williamson, 2009). In turn, effective rural principals find a middle ground by addressing the local context while simultaneously validating school district policy (Cruzeiro \& Morgan, 2009; Latham et al., 2014; Schuman, 2010). In other words, successful rural principals are efficient at balancing local expectations and the educational vision of the centralized school district. These principals understand how local, district, and nationwide contexts influence the rural school and respond in ways that are both place-conscious and mandateresponsive. 
Instructional leader. The effective rural principal is a strong instructional leader. Studies highlight that a successful rural leader promotes a professional school culture where teachers feel empowered to try new ideas and take well-calculated risks (Chance \& Segura, 2009; Renihan \& Noonan, 2013). Often rural principals assume a teaching assignment in addition to administrative responsibilities; in turn, they are well-situated to provide firsthand curricular and instructional guidance. Moreover, often for rural principals, instructional leadership is about leading through role modelling, and the principal as instructional leader sometimes personally conducts professional development workshops for teachers (Newton \& Wallin, 2013; Klar \& Brewer, 2014; Wallin \& Newton, 2013). Successful rural principals advocate and promote quality professional development for staff (Tom, 2012). Acts of instructional leadership are also exemplified by rural principals who consistently recognize teacher achievements through formal and informal awards and positive communications (Klar \& Brewer, 2014). Rural teachers want to be led by school leaders who recognize and value teacher accomplishments (Msila, 2012; Pashiardis et al., 2011). As well, a few studies reflected that rural leaders were especially successful at enhancing and perfecting the special education program within the school (Cruzeiro \& Morgan, 2009; Irvine et al., 2010; Schuman, 2010).

The successful instructional leader of a rural school has a clear focus on a style of instruction that supports high academic standards for students (Klar \& Brewer, 2014; Kornfield, 2010; Masumoto \& Brown-Welty, 2009; Nor, Pihie, \& Ali, 2008; Star \& White, 2008). Effective rural principals raise expectations of teachers by endorsing on-grade reading levels of students (Tom, 2012) and by promoting student improvement on standardized tests (Barbour, 2014; Tom, 2012). A study with administrators of three high schools in high-poverty areas of rural California effectively employed instructional leadership practices to improve student outcomes in the school (Masumoto \& Brown-Welty, 2009). In doing so, these principals established formal and informal connections with associations and institutions outside the school in order to positively affect student achievement.

\section{Implications and Future Research}

To reiterate the main question of this article: what are the traits, actions, and behaviors of successful school leaders? Some words that succinctly address this question include: accommodating, supportive, community-focused, team-builder, cooperative, visionary, and decisive. The common idea threaded throughout these words and throughout the aforementioned studies is collaboration. Regardless of the school's location, the dynamics of the staff, or the number, type, or grade level of students, a rural principal who fosters rich, collaborative relationships with teachers, students, parents, community members, and senior educational leaders is positioned to succeed.

There are positive implications associated with a school principal who assumes and endorses a collaborative style of leadership. Collaborative leadership is founded on the belief that people are the most valuable resource of any organization or community. A school principal who cultivates collaborative relationships within the school community is a person who promotes and endorses public education that can meet the challenges that many rural communities face in the 21 st century (Harmon \& Schafft, 2009). Some of these many challenges include decreasing student enrollment, transient teachers, lack of specialized teachers, and transportation issues. A school principal who calls upon the knowledge, skills, and experience that is housed within members of the entire school community generates a productive, informed school community, which can collectively solve such problems and, ultimately, celebrate success. The collective knowledge, abilities, and potential of any dedicate group of people is far more influential and powerful than the sum of non-interpersonal energies and actions. Moreover, a collaborative educational culture cultivates problem-solvers, uncovers and takes advantage of opportunities, and fosters additional collaborations, committees, coalitions, networks, and partnerships. In such a fashion, collaborative leadership recognizes the best in people and uses the constructive power of the school community to promote, produce, and publicize student success and wellbeing.

Herein, we paraphrased common characteristics of successful rural principals, however, further research is required to more fully understand the collaborative place-conscious role of school leaders in rural schools. More research needs to be conducted on 
identifying characteristics, features, and traits needed to support and sustain a successful, collaborative leadership experience in a rural school. In what ways can principals effectively foster and utilize family-school connections within rural settings to promote student achievement? What specific leadership practices, behaviors, and beliefs increase student achievement and wellbeing in a rural school? How can the social capital imbued within school leadership and the personal and professional networks within rural communities be effectively utilized to constructively inform student learning?
What types of personal and professional supports might assist rural principals promoting the placebased needs of students and community while simultaneously advocating the mandates outlined by school districts? Additional research is also needed with regard to rural school principals and their responsibilities, beliefs, and practices associated with students experiencing learning disabilities, learning differences, and English as an Additional Language issues. These questions represent just a few research topics waiting to be addressed through future studies about school leadership in rural communities.

\section{References}

Agnitsch, K., Flora, J., \& Ryan, V. (2009). Bonding and bridging social capital: The interactive effects on community action. Journal of the Community Development Society, 37(1), 36-51. doi:10.1080/15575330609490153

Alberta Government. (2012). Promising practices in rural elementary education. Edmonton, AB: Author. Retrieved from https://education.alberta.ca/media/6807246/rura 1\%20education $\% 20$ report.pdf

Anderson, M., Davis, M., Douglas, P., Lloyd, D., Niven, B., Thiele, H. (2010). A collective act: Leading a small school. Melbourne, Australia: ACER Press.

Anderson, M., \& White, S. (2011). Resourcing change in small schools. Australian Journal of Education, 55(1), 50-61.

Ashton, B., \& Duncan, H. E. (2012). A beginning rural principal's toolkit: A guide for success. The Rural Educator, 34(1), 19-30.

Australian Bureau of Statistics. (2011). Australian Statistical Geography Standard (ASGS).

Retrieved from

http:/www.abs.gov.au/ausstats/abs@.nsf/Looku $\mathrm{p} / 2901.0$ Chapter23102011

Australian Government. (2013). Rural, Remote and Metropolitan Areas (RRMA) classification. Retrieved from http://www.aihw.gov.au/ruralhealth-rrma-classification/

Barbour, N. N. (2014). Principal leadership and standards: Lesson learned in three rural high schools that participated in North Carolina's turnaround initiative. Unpublished doctoral dissertation. North Carolina State University, Raleigh, NC.

Barley, Z. A., \& Beesley, A. D. (2007). Rural school success. What can we learn? Journal of Research in Rural Education, 22(1), 1-16.
Bartling, E. M. (2013). Female high school principals in rural Midwestern school districts: Their lived experiences in leadership. Unpublished doctoral dissertation. University of Wisconsin-Milwaukee, Milwaukee, WI.

Boeije, H. (2008). Analysis in qualitative research. Thousand Oaks, CA: Sage.

Bollman, R. D., \& Alasia, A. (2011). A profile of self-employment in rural and small town Canada: Is there an impending retirement of self-employed business operators? The Daily, 9(1), 1-38.

Bourdieu, P. (1986). The forms of capital. In J. Richardson (Ed.), Handbook of theory and research for the sociology of education (pp. 241-258). New York, NY: Greenwood Press.

Bowen, G. A. (2009). Document analysis as a qualitative research method. Qualitative Research

Journal, 9(2), 27-40. doi:10.3316/QRJ0902027

Budge, K. (2006). Rural leaders, rural places: Problems, privilege, and possibility. Journal of Research in Rural Education, 27(13), 1-10. Canadian Council on Learning. (2006, March). Lessons in learning: The rural-urban gap in education. Retrieved from http://www.nald.ca/library/research/ccl/rural ur ban gap ed/rural urban gap ed.pdf

Chance, P. L., \& Segura, S. N. (2009). A rural high school's collaboration approach to school improvement. Journal of Research in Rural Education, 24(5), 1-11.

Clarke, S., \& Stevens, E. (2009). Sustainable leadership in small rural schools: Selected Australian vignettes. Journal of Educational Change, 10(4), 277-293. dio:10.1007/s10833008-9076-8 
Coleman, J. S. (1988). Social capital in the creation of human capital. American Journal of Sociology, 94(Spec. Ed.), S95-S120.

Cooper, H., Patall, E., \& Lindsay, J. (2009). Research synthesis and meta-analysis. In L. Bickman \& D. Rog (Eds.), The Sage handbook of applied social research methods (2nd ed., pp. 344-371). Thousand Oaks, CA: Sage.

Cortez-Jiminez, G. (2012). Leadership needs of California rural school administrators. Unpublished doctoral dissertation. San Diego State University, San Diego, CA.

Cruzeiro, P. A., \& Boone, M. (2009). Rural and small school principal candidate: Perspectives of hiring superintendents. The Rural Educator, 31(1), 1-9.

Cruzeiro, P. A., \& Morgan, R. L. (2009). The rural principal's role with consideration for special education. Education, 126(3), 569-579. Abstract retrieved from http://eric.ed.gov/?id=EJ765776

Day, C., Sammons, P., Leithwood, K., Hopkins, D., Gu, Q., Brown, E., \& Ahtaridou, E. (2011). Successful school leadership: Linking with learning and achievement. Maidenhead, England. McGraw Hill Education.

Dinham, S. (2008). How to get your school moving and improving. Melbourne, Australia: ACER Press.

Glass, G. V. (1976). Primary, secondary and metaanalysis. Educational Researcher, 5(10), 3-8. Gov.UK. (2015). Rural urban classification. Retrieved from https://www.gov.uk/government/collections/rur al-urban-definition

Haar, J. M. (2007). Retaining experienced, qualified teachers: The principal's role. The Rural Educator, 28(2), 28-34.

Halpern, D. (2005). Social capital. Cambridge, England: Polity Press.

Halsey, R. J., \& Drummond, A. (2014). Reasons and motivations of school leaders who apply for rural, regional and remote locations in Australia. Australian and International Journal of Rural Education, 24(1), 69-77.

Harmon, H. L., \& Schafft, K. (2009). Rural school leadership for collaborative community development. The Rural Educator, 50(3), 4-9.

Heck, R. H., \& Halliger, P. (2009). Assessing the contribution of distributed leadership to school improvement and growth in math achievement.
American Educational Research Journal, 46(3), 659-689. dio:10.3102/0002831209340042

Hnatkovska, V., \& Lahiri, A. (2013, February). The rural-urban divide in India. London, England: International Growth Center. Retrieved from http://www.theigc.org/wpcontent/uploads/2014/09/Hnatkovska-Lahiri2012-Working-Paper-March.pdf

Irvine, A., Lupart, J. L., Loreman, T., \& McGhieRichmond, D. (2010). Educational leadership to create authentic inclusive schools: The experiences of principals in a Canadian rural school district. Exceptionality Education International, 20(2), 70-88.

Jentz, B., \& Murphy, J. (2005). Starting confused: How leaders start when they don't know where to start. Phi Delta Kappan, 91(1), 56-60.

Jordan, J. L., Kostandini, G., \& Mykerezi, E. (2012). Rural and urban high school dropout rates: Are they different? Journal of Research in Rural Education, 27(12), 1-21.

Kawana, J. J. (2007). The principal's leadership role in a successful rural school in Namibia. Unpublished master's thesis. Rhodes University, Grahamstown, South Africa.

Klar, H. W., \& Brewer, C. A. (2014). Successful leadership in a rural, high-poverty school: The case of County Line Middle School. Journal of Educational Administration, 52(4), 422-445.

Kornfield, M. (2010). The effects of class size on student academic achievement in a rural state. Unpublished doctoral dissertation. University of Vermont, Burlington, VT.

Lamb, S., Glover, S., \& Walstab, A. (2014, August). Educational disadvantage and regional rural schools. Paper presented at the Australian Council for Educational Research (ACER) Research Conference, Melbourne, Australia.

Latham, D., Smith, L. F., \& Wright, K. A. (2014). Context, curriculum, and community matter:

Leadership practices of primary school principals in the Otago province of New Zealand. The Rural Educator, 36(1), 1-12.

Leithwood, K., Harris, A. \& Hopkins, D. (2008). Seven strong claims about successful school leadership. School Leadership \& Management, 28(1), 27-42. doi:10.1080/13632430701800060

Lester, N. C. (2011). Relationship building: Understanding the extent and value. Education in Rural Australia, 21(1), 79-93. 
Littell, J. H., Corcoran, J., \& Pillai, V. (2008). Systematic reviews and meta-analysis. New York, NY: Oxford University Press

Lock, G., Budgen, F., \& Lunay, R. (2012). The loneliness of the long-distance principal: Tales from remote Western Australia. Australian and International Journal of Rural Education, 22(2), 65-77.

Louis, K. S., Dretzke, B., \& Wahlstrom, K. (2010). How does leadership affect student achievement? Results from a national US survey. School Effectiveness and School Improvement, 21(3), 315-336.

Machi, L. A., \& McEvoy, B. T. (2012). The literature review: Six steps to success (2nd ed.). Thousand Oaks, CA: Sage.

Masumoto, M., \& Brown-Welty, S. (2009). Case study of leadership practices and schoolcommunity interrelationships in highperforming, high-poverty, rural California high schools. Journal of Research in Rural Education, 24(1), 1-18.

Moffitt, J. (2007). What works: Principal leadership behaviors that positively impact student achievement in elementary schools. Unpublished doctoral dissertation. Georgia Southern University, Statesboro, GA,

Morrow, J. (2012). Through the lens of the rural lifeworld: A phenomenological investigation of the rural school principal. Unpublished doctoral dissertation. Simon Fraser University, Victoria, BC.

Msila, V. (2012). Rural school principals' quest for effectiveness: Lessons from the field. Journal of Education, 48(1), 169-189.

National Center for Education Statistics. (2013). The status of rural education. Retrieved from http://nces.ed.gov/programs/coe/indicator tla.as p

Neuendorf, K. A. (2002). The content analysis guidebook. Thousand Oaks, CA: Sage.

Newton, P., \& Wallin, D. C. (2013). The teaching principal: An untenable position or a promising model? Alberta Journal of Educational Research, 59(1), 55-71.

Nor, S. M., Pihie, Z. A. L., \& Ali, S. (2008). Instructional leadership practices of rural school principals. International Journal of Learning, 15(70), 231-238.

NSW [North South Wales] Government. (2013, November). Rural and remote education: A blueprint for action. Retrieved from https://www.det.nsw.edu.au/media/downloads/a

bout-us/our-reforms/rural-and-remoteeducation/randr-blueprint.pdf

OECD [Organisation of Economic Cooperation and Development]. (2013). PISA in focus: What makes urban school different? Retrieved from http://www.oecd.org/pisa/pisaproducts/pisainfo cus $/$ pisa $\% 20 \mathrm{in} \% 20$ focus $\% 20$ n28\%20(eng)-FINAL.pdf

Panizzon, D. (2012). Science education in rural settings: Exploring the 'state of play' internationally. In B. J. Fraser, K. G. Tobin, \& C. J. McRobbie (Eds.). Second international handbook of science education (Vol. 1, pp. 527-540). New York, NY: Springer.

Pashiardis, P., Savvides, V., Lytra, E., \& Angelidou, K. (2011). Successful school leadership in rural contexts: The case of Cyprus. Educational Management Administration \& Leadership, 39(5), 536-553.

Patton, M. Q. (2015). Qualitative research \& evaluation methods (4th ed.). Los Angeles, CA: Sage.

Pietsch, B., \& Williamson, J. (2009, July). Beyond the black stump: Dilemmas and tensions facing new principals in remote NSW. Paper presented at the Annual Conference of the Australian Teacher Education Association (ATEA), Albury, Australia.

Preston, J. P. (2012). Rural and urban teaching experiences: Narrative expressions. Alberta Journal Educational Research, 58(1), 41-57.

Preston, J. P., Jakubiec, B. A. E., \& Kooymans, R. (2013). Common challenges faced by rural principals: A review of the literature. Rural Educator, 35(1), 1-12.

Prior, L. (2003). Using documents in social research. Thousand Oaks, CA: Sage.

Putnam, R. D. (2000). Bowling alone: The collapse and revival of American community. New York, NY: Simon \& Schuster.

Renihan, P., \& Noonan, B. (2012). Principals as assessment leaders in rural schools. The Rural Educator, 33(3), 1-8.

Robinson, V. (2011). Student-centered leadership. San Francisco, CA: Jossey-Bass.

Schuman, A. L. (2010). Rural high school principals: Leadership in rural education. Unpublished doctoral dissertation. Temple University, Philadelphia, PA. 
Schwandt, T. A. (2007). The Sage dictionary of qualitative inquiry (3rd ed.). Thousand Oaks, CA: Sage.

Sebastian, J., \& Allensworth, E. (2012). The influence of principal leadership on classroom instruction and student learning: A student of mediated pathways to learning. Educational Administration Quarterly, 48(4), 626-663. dio: $10.1177 / 0013161 X 11436273$

Seipert, K., \& Baghurst, T. (2014). Contrasting work values of baby boomers and generation $\mathrm{x}$ rural public school principals. Public Administration Quarterly, 38(3), 347-370.

Starr, K., \& White, S. (2008). The small rural school principalship: Key challenges and cross-school responses. Journal of Research in Rural Education, 23(5), 1-12.

Statistics New Zealand. (n.d.). Defining urban and rural New Zealand. Retrieved from http://www.stats.govt.nz/browse for stats/Map $\mathrm{s}$ and geography/Geographic-areas/urbanrural-profile/defining-urban-rural-nz.aspx\#rural

Surface, J. L., \& Theobald, P. (2015). What is rural school leadership? In D. Griffiths \& J. P. Portelli (Eds.), Key questions for educational leaders (pp. 145-149). Burlington, ON: Word $\&$ Deed.
Tom, D. F. (2012). Principals in two high achieving elementary schools in New Mexico: A case study. Unpublished doctoral dissertation. Arizona State University, Tempe, AZ.

United Nations. (2013). Population density and urbanization. Retrieved from http://unstats.un.org/unsd/demographic/sconcer ns/densurb/densurbmethods.htm

United States Census Bureau. (2015). Urban and rural classifications. Retrieved from http://www.census.gov/geo/reference/urbanrural.html

Wallace, A., \& Boylan, C. (2007). Leading in the small rural school: The case of the novice principal. Leading and Managing, 11(1), 43-56.

Wallin, D., \& Newton, P. (2013). Instructional leadership of the rural teaching principal: Double the trouble or twice the fun? International Studies in Educational Administration, 41(2), 19-31.

Walsh, D., \& Downe, S. (2005). Meta-synthesis method for qualitative research: A literature review. Journal of Advanced Nursing, 50(2), 204-211.

Zacharakis, J., Devin, M., \& Miller, T. (2008). Political economy of rural schools in the heartland. Rural Special Education Quarterly, 27(3), 16-22.

\section{About the authors:}

Jane P. Preston is an Assistant Professor in the Faculty of Education at the University of Prince Edward Island (Canada). Her research interests include: educational leadership, Indigenous issues, the internationalization of higher education, and parent involvement in school. Her contact information is jpreston@upei.ca

Kristopher E. R. Barnes has been a teacher and administrator for 14 years. He is currently teaching in the Saskatoon Public School system. His research interests include: educational leadership, curriculum, and parental expectations of school, students, and teachers. His contact information is barnesk@spsd.sk.ca 